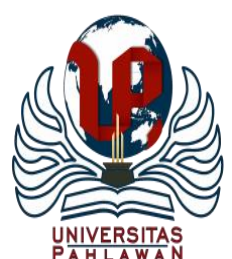

Jurnal Abdidas Volume 2 Nomor 4 Tahun 2021 Halaman 758-766

JURNAL ABDIDAS

http://abdidas.org/index.php/abdidas

\title{
Sosialisasi Strategi Kreatif Produksi Film Di Era New Normal
}

\author{
FX. Yatno Karyadi ${ }^{1 凶}$, Choiru Pradhono \\ Televisi dan Film, ISI Padangpanjang, Indonesia ${ }^{1,2}$ \\ E-mail: yatnokaryadi@isi-padangpanjang.ac.id ${ }^{1}$ choirupradhono@isi-padangpanjang.ac.id ${ }^{2}$
}

\begin{abstract}
Abstrak
Sejak terjadinya pandemi Covid-19, usaha-usaha di bidang produksi audio-visual ditutup, bioskop dan art space untuk apresiasi karya film juga tidak beroperasi. Usaha persewaan alat produksi film tidak mendapatkan hasil. Pada bidang pendidikan film, perguruan tinggi meliburkan mahasiswa dan aktivitas belajar mengajar dilakukan secara online. Dalam hal produksi film new normal adalah membuka kembali aktivitas produksi film secara terbatas, dengan menggunakan standar kesehatan yang tidak ada sebelum pandemi. Hal ini adalah upaya mengembalikan kegiatan produksi film menggunakan adaptasi dan kebiasaan baru, untuk menjaga agar pekerja film dan mahasiswa film tetap berdaya dan kembali berkarya. Produksi film di era new normal dapat dilakukan dengan menyesuaikan beberapa hal penting dalam produksi film yang meliputi penyesuaian ide dan penuturan cerita, tata cara penyelenggraan dan manajemen produksi, serta melakukan kompromi dengan berbagai peraturan dan anjuran tentang kesehatan.
\end{abstract}

Kata kunci: sosialisasi, strategi kreatif, produksi film, new normal

\begin{abstract}
Since the Covid-19 pandemic, businesses in the audio-visual production sector have been closed, cinemas and art spaces for film appreciation have also stopped operating. The business of renting film production equipment is not getting any results. In the field of film education, universities have closed students and teaching and learning activities are carried out online. In terms of film production, the new normal is to reopen film production activities on a limited basis, using health standards that did not exist before the pandemic. This is an effort to restore film production activities using adaptations and new habits, to keep film workers and film students empowered and return to work. Film production in the new normal era can be done by adjusting several important things in film production which include adjusting ideas and storytelling, procedures for organizing and managing production, as well as making compromises with various regulations and recommendations regarding health.
\end{abstract}

Keywords: socialization, creative strategy, film production, new normal

Copyright (c) 2021 FX. Yatno Karyadi, Choiru Pradhono

$\triangle$ Corresponding author

Address : ISI Padangpanjang

Email : yatnokaryadi@isi-padangpanjang.ac.id

DOI : https://doi.org/10.31004/abdidas.v2i4.309

ISSN 2721- 9224 (Media Cetak)

ISSN 2721- 9216 (Media Online)

Jurnal Abdidas Vol 2 No 4 Tahun 2021 p-ISSN 2721-9224 e-ISSN 2721-9216 


\section{PENDAHULUAN}

Terjadinya pandemi Covid-19 sejak akhir tahun 2019 menyebabkan berbagai sektor kehidupan berhenti berproduksi. Termasuk produksi di bidang kreatif seperti produksi film. Setelah sekian lama berdiam diri di rumah, dan adanya kebijakan Pembatasan Sosial Berskala Besar (PSBB), timbul kesadaran bahwa tidak mungkin selamanya bertahan tanpa berbuat apapun. Istilah new normal atau yang disebut sebagai adaptasi kebiasaan baru, kemudian diperkenalkan untuk menggambarkan upaya penyesuaian-penyesuaian dan perubahanperubahan yang harus diterapkan sebagai respons atas pandemi Covid-19 (Mas'udi \& Winanti, 2020).

Sasaran sosialisasi ini adalah para pekerja film dan mahasiswa bidang film. Selama pademi berlangsung, para pekerja film tidak dapat melaksanakan produksi untuk memenuhi permintaan industri, sedangkan mahasiwa bidang film tidak dapat melaksanakan praktek produksi untuk keperluan studi. Tujuannya adalah untuk mengaktifkan kembali produksi film, agar dampak ekonomi pada pendapatan pekerja film segera membaik. Selain itu juga agar mahasiswa bidang film tidak kehilangan kesempatan untuk melakukan magang kerja di industri film.

Sejak terjadinya pandemi Covid-19, usaha-usaha di bidang produksi audio-visual ditutup, bioskop dan art space untuk apresiasi karya film juga tidak beroperasi. Usaha persewaan alat produksi film tidak mendapatkan hasil. Pada bidang pendidikan film, perguruan tinggi meliburkan mahasiswa dan aktivitas belajar mengajar dilakukan secara online. Tuntutan belajar dalam bentuk praktek produksi film tidak dapat dilaksanakan.

New normal adalah tahapan setelah kebijakan stay at home, work and study from home, dan PSBB, tujuan utamanya adalah untuk mencegah secara masif dari penyebaran virus corona (Noor, 2020). Hal ini dilakukan karena kesadaran bahwa tidak mungkin terus menerus bersembunyi di rumah tanpa kepastian akan jangka waktu berlangsungnya pandemi.

Dalam hal produksi film new normal adalah membuka kembali aktivitas produksi film secara terbatas, dengan menggunakan standar kesehatan yang tidak ada sebelum pandemi. Hal ini adalah upaya mengembalikan kegiatan produksi film menggunakan adaptasi dan kebiasaan baru, untuk menjaga agar pekerja film dan mahasiswa film tetap berdaya dan kembali berkarya.

New normal membuka kesempatan agar pekerja film dan mahasiswa film bisa menjalani passion mereka. Hal ini dilandasi sepenuhnya atas kesadaran bahwa wabah virus corona masih ada di sekitar kita. Karenanya, produksi film dilakukan dengan menerapkan 
protokol kesehatan yang ditetapkan. Pekerja film membutuhkan pemasukan finansial dan mahasiswa perfilman butuh pengalaman.

\section{METODE}

Mitra pengabdian ini adalah mahasiswa dari beberapa perguruan tinggi seni yang memiliki Program Studi Film dan Televisi. Kegiatan dilaksanakan pada tanggal 19-20 Oktober 2020 secara daring melalui aplikasi Zoom Meeting dan live streaming di Youtube. Metode yang dilakukan berupa ceramah dan demonstrasi. Metode yang digunakan adalah sosialisasi partisipatif. Materi berupa pengenalan situasi produksi, strategi kreatif dalam masa pendemi, dan berbagi pengalaman produksi selama pandemi dari praktisi yang telah melakukan prosedur produksi dan protokol kesehatan selama pandemi berlangsung.

Demonstrasi dilakukan dengan memperagakan dan menunjukkan dokumentasi prosedur kerja dalam produksi film yang sesuai protokol kesehatan. Contohcontoh rapat produksi secara online yang efektif, pemakaian masker bagi kerabat kerja produksi, prosedur menjaga jarak aman, sanitizing dan sterilisasi peralatan produksi, prosedur makan dan minum dan isolasi mandiri.

Tahapan kegiatan meliputi: perencanaan dan persiapan, (2) pelasanaan kegiatan secara daring dengan materi: strategi kreatif produksi film di masa pandemi, prosedur dan protokol kesehatan bagi kerabat kerja produksi film, dan berbagi pengalaman dengan praktisi produksi film disertai tanya jawab, (3) evaluasi dan sosialisasi panduan produksi film di era new normal. Draf panduan telah disusun sebelumnya berdasar protokol kesehatan dari Kementerian Kesehatan, Badan Perfilman Indonesia dan panduan dari organisasi profesi bidang perfilman.

\section{HASIL DAN PEMBAHASAN}

\section{Kreativitas}

Dalam pemaparan yang berjudul Keterbatasan, Kreativitas dan Film, narasumber Choiru Pradhono memberi gambaran umum tentang bagaimana strategi kreatif dalam produksi film di era new normal. Materi ini memuat gambaran tentang proses kreatif dalam keterbatas karena ruang gerak, lingkungan dan materi yang dikerjakan dalam produksi film di masa pandemi mengalami pergeseran dan perbedaan-perbedaan. Ide cerita yang dikembangkan harus memungkinkan untuk diproduksi dengan melibatkan lebih sedikit orang dibanding pada situasi normal.

Pokok materinya adalah bagaimana menyikapi perbedaan situasi ini, agar produksi tetap berjalan, tetap sehat, tidak melanggar peraturan dan tetap bisa berkarya. Batasan adalah pagar atau 
bingkai yang membuat pengkarya berpikir untuk tidak melanggarnya. Strategi yang diperlukan berupa analisa, rencana dan dilanjutkan dengan konsolidasi. Analisa dibutuhkan untuk membuat keputusan yang menyatakan bahwa produksi film bisa dilakukan atau tidak. Hal ini bisa berhubungan dengan kualitas materi, target, skala produksi dan sifatnya, untuk profesional, pendidikan atau untuk komersial.

Kreativitas akan menyangkut reaksireaksi pada pribadi orang per orang, proses yang dilakukan dan produk yang akan dihasilkan. Orang sebagai pribadi dituntut mempunyai nalar dan mampu mencari jalan keluar. Memiliki pemikiran tentang cara mencari solusi atas kondisi tertentu. Ada keberanian untuk mencoba yang baru, yang tidak sama seperti yang sebelumnya pernah ada.

Proses akan berhubungan dengan halhal yang akan dilakukan. Solusi awal yang telah dipikirkan pun belum tentu berhasil. Sedangkan produk dari proses belum tentu sekali jadi. Kegagalan bisa terjadi berkalikali atau selalu gagal di tiap tahapannnya. Pengalaman atas kegalan ini akan menghasilkan materi yang berbeda. Solusi akan ditemukan saat formula baru yang paling memungkinkan dipandang masih memenuhi kaidah-kaidah perfilman.
Dalam hal produksi film, maka perlu dipahami tentang apakah film itu? Film adalah cerita yang dituturkan kepada penonton melalui rangkaian gambar bergerak (Armantono \& Pramita, 2013). Jawaban atas apakah cerita itu, atau apakah bertutur itu dan apakah gambar bergerak itu, akan menjadi jalan untuk menemukan sebuah solusi. Kuncinya adalah bahwa film adalah media visual. Jadi gambarlah yang akan bertutur. Landasan berfikirnya adalah idenya apa? Bahwa ide itu harus jelas, sederhana dan menarik.

Ide masih harus disesuaikan dengan kondisi yang paling memungkinkan. Ketika tidak ada celah untuk melibatkan banyak peran, tentu cerita yang melibatkan dua pemeran saja misalnya, menjadi lebih masuk akal untuk dikerjakan. Ide harus dikembangkan menjadi sesuatu yang menarik, yaitu harus punya pesan yang hendak disampaikan. Sedangkan secara visual akan menggunakan prinsip bahwa gambar harus bisa memperlihatkan, bukan sekedar menceritakan. Setiap gambar yang disajikan harus memuat informasi penting yang berhubungan dengan si tokoh dan tujuan besar yang ingin ia capai.

Cerita akan mengalir jika si tokoh memiliki konflik, yaitu hambatan dalam mencapai tujuannya. Mengemas cerita yang telah ditetapkan dalam durasi 
tertentu, memiliki perlakuan yang berbedabeda terutama pada seberapa banyak konflik yang harus ada di dalam cerita. Dengan kesadaran tentang keterbatasanketerbatasan di masa pandemi ini, pencarian konsep bisa saja benar-benar bermula pada hal-hal kecil dan sepele yang sedang dialami oleh semua orang. Kreativitas terletak pada bagaimana membuat keganjilan-keganjilan yang menyebakan konflik-konflik agar cerita dapat berjalan.

\section{Tata Laksana Dan Tata Kelola Produksi}

Sesi ini membahas hal-hal strategis yang berhubungan dengan manajemen produksi. Narasumber FX. Yatno Karyadi merupakan akademisi bidang produksi film membawakan materi tentang manajemen produksi film dengan judul Ayo Syuting (lagi). Secara teknis, produksi film di masa pandemi akan mengalami penyesuaian bagi kerabat kerja produksi. Penyesuaian ini utamanya bertujuan demi kesehatan dan keselamatan kerja. Bukan saja dari resiko kerja produksi film saja, melainkan juga resiko kesehatan dan keselamatan akibat adanya pandemi Covid-19.

Dalam pengelolaan produksi film di era new normal, akan terdapat penyesuaian-penyesuaian pada aspek produksi. Misalnya, ketika ditemukan ide dasar pada cerita yang melibatkan lansia dan anak-anak. Ide ini bisa saja dieksekusi sampai tahap produksi, dengan pertimbangan bahwa pemeran yang terlibat hanya terdiri dari dua orang saja. Namun, pertimbangan produksi new normal mensyaratkan bahwa usia yang direkomendasikan untuk terlibat dalam produksi film adalah 13-50 tahun. Maka, prioritas bisa bergeser menjadi mementingkan aspek penceritaan dibanding dengan pemerannya. Hal ini sudah akan terdeteksi pada tahap praproduksi ketika mengembangkan ide.

Pada aspek finansial mungkin akan mengakibatkan mata anggaran yang lebih mahal karena departemen produksi harus menyediakan sarana penunjang kesehatan sesuai protokol penanganan Covid-19. Akan ada belanja masker, biaya sarana cuci tangan, hand sanitizer, biaya tes kesehatan untuk semua kru dan sebagaianya. Atau, di sisi lain justru anggaran bisa dipangkas menjadi lebih murah, karena proses produksi tidak melibatkan banyak kerabat kerja, meminimalisir jumlah kru yang terlibat dan berbagai pekerjaan dapat dilakukan oleh satu orang dengan merangkap jabatan.

Prinsip dasar produksi film dalam era new normal adalah menghindari terinfeksi. Sehingga, semua usaha dan upaya 
pencegahan penularan virus corona wajib dilakukan. Usaha yang paling masuk akal untuk dilakukan adalah menyederhanakan konsep produksi dan meminimalisir jumlah personel yang terlibat guna menghindari berkerumun.

Protokol kesehatan yang wajib dilakukan dalam produksi film adalah mewajibkan seluruh kru melakukan tes kesehatan sebelum berangkat produksi. Di lokasi syuting seluruh orang yang terlibat wajib menggunakan masker, menjaga jarak aman dan menggunakan hand sanitizer. Menjaga kesehatan pribadi dilakukan dengan mencuci tangan dengan sabun menggunakan air mengalir, makan dan minum menggunakan peralatan makan dan minum pribadi, dan juga mensterilisasi seluruh peralatan produksi yang dipegang begantian seperti peralatan kamera, peralatan lighting, tata suara dan peralatan pendukung lainnya.

Pada aspek manjemen, disadari sejak semula bahwa produksi film terdiri dari tahapan-tahapan yaitu tahap pengembangan, pra-produksi, produksi dan pasca-produksi (Pats, 2010). Setelah ide disepakati dan dikembangkan, pada tahap pra-produksi akan terdapat banyak rapat produksi. Proses ini akan memanfaatkan teknologi komunikasi, misalnnya dengan video call atau aplikasi rapat online. Tim produksi dan tim lokasi wajib memiliki catatan khusus mengenai kondisi lokasi apakah termasuk dalam zona aman untuk produksi. Perijinan juga menyangkut kemungkinan bahwa beberapa lokasi mungkin tidak mengizinkan orang luar untuk masuk di lokasi tertentu.

Saat produksi, semua hal yang berhubungan dengan penjadwalan perlu dipertimbangkan. Jumlah jam kerja diupayakan agar senantiasa menjaga vitalitas kerabat kerja, mendapat asupan makanan sehat dan istirahat yang cukup. Suasana hati saat bekerja tidak merasa tertekan. Departemen produksi memfasilitasi seluruh sarana untuk menjaga kesehatan dan meminimalisir perpindahan lokasi, melokalisir lokasi produksi sekaligus mengisolasi seluruh kerabat produksi agar tidak terhubung dengan lingkungan di luar area produksi.

\section{Dampak Pandemi Pada Perfilman}

Materi berjudul Dampak Pandemi Pada Perfilman Indonesia disampaikan oleh naarasumber Budi Arifianto, seorang praktisi film asal Yogyakarta. Dalam kenyataannya pandemi ini berimbas pada dunia produksi, bukan hanya di Indonesia, tetapi terjadi di seluruh dunia. Yang paling terdampak adalah dunia industri, termasuk para pekerja film dan sekolah perfilman. 
Pandemi juga melumpuhkan bisnis global di bidang usaha bioskop.

Dari sisi produksi, sejak Maret 2020 tidak ada produksi film di Indonesia. Mediasi dan konsolidasi dilakukan melalui teknologi komunikasi. Memasuki era new normal, Badan Perfilman Indonesia (BPI) menerbitkan draft Protokol Produksi Audio Visual Pada Fase Pemulihan Covid19 (BPI, 2020). Salah satu poin pentingnya adalah adanya kewajiban melakukan tes kesehatan negatif corona melalui tes swab atau rapid test. Biaya tes swab yang cukup mahal, terasa menjadi beban bagi produksi film di kalangan mahasiswa dan komunitas.

Dalam draft tersebut juga diatur beberapa ketentuan lain diantaranya mengenai jam kerja produksi film paling lama selama 15 jam kerja dan maksimal selama 3 hari. Catering, cara makan dan peralatan makan pribadi juga diatur agar tidak saling berbagi alat makan minum. Pemeran atau talent yang terlibat adalah usia 13-15 tahun, yang artinya tidak dapat melibatkan usia lanjut dan anak-anak.

Dalam kondisi yang serba sulit, opsiopsi agar produksi karya film tidak berhenti selalu dipikirkan. Harus tetap muncul karya film dalam masa pandemi ini sebagai bagian dari sejarah tentang dunia, sejarah tentang pandemi Covid-19 dan juga sejarah bagi perfilman itu sendiri.
Kemudian muncullah ide-ide untuk memanfaatkan apa yang terlihat dan terjadi sehari-hari di lingkungan sekitar selama pandemi. Banyak produksi film yang mengambil cerita berdasar komunikasi yang dilakukan oleh orang-orang pada video call atau Zoom Metting.

Pada tataran komunitas, pembuatan film dilakukan di lokasi-lokasi tempat komunitas berada. Artinya akan memangkas proses seperti pencarian dan perijinan lokasi, mengguanakan pemeran dari kalangan komunitas itu sendiri, bekerja sama dengan tim produksi yang sudah saling kenal dan tahu pasti riwayat kesehatannya, atau bekerjasama dengan komunitas tertentu, atau kampungkampung yang terbuka dengan kegiatan produksi film. Tentunya karena tinggal di suatu lokasi, otomatis melakukan isolasi selama syuting.

Selanjutnya dilakukan demonstrasi prosedur produksi dalam masa pendemi kepada peserta. Narasumber memperagakan prosedur yang harus dilakukan selama produksi. Prosedur ini cukup mudah karena mengadopsi protokol kesehatan yang juga disosialisasikan oleh Kementerian Kesehatan, Gugus Tugas Covid-19 dan Badan Nasional Penanggulangan Bencana (BNPB).

Rapat produksi dilakukan melalui video call, aplikasi video converence atau 
aplikasi rapat. Selama syuting seluruh kerabat kerja wajib menggunakan masker. Melakukan sanitizing untuk tangan dan peralatan produksi. Sebelum dan sesudah makan atau jika melakukan kontak dengan benda-benda properti syuting melakukan cuci tangan dengan sabun pada air mengalir atau melakukan hand sanitizing. Menggunakan alat makan minum pribadi, menjaga jarak aman dan sterilisasi lingkungan produksi.

Apa yang akan terjadi selanjutnya? Pandemi corona sulit diprediksi kapan akan benar-benar berakhir. Oleh sebab itu, pandemi Covid-19 ini justru menjadi akselerasi. Film di masa depan diprediksi akan mengalami pergeseran. Saluran menonton dan distribusi menjadi beragam. Penyesuain di era pandemi akan menjadikan film memiliki ciri yang semakin menarik dengan penemuanpenemuan cara bertutur yang baru.

Konsep distribusi baru dalam dunia produksi film mulai terjadi. Bila pandemi tidak segera berakhir, bioskop bisa saja menjadi heritage, dan pergi menonton bioskop mungkin hanyalah alternatif untuk mencari cinematic exsperience saja. Alternatifnya adalah platform online dan distribusi film melalui saluran internet. Pembuat film harus berkompromi dan banyak akal. Selanjutnya, tinggal
memastikan kualitas output hasi produksinya.

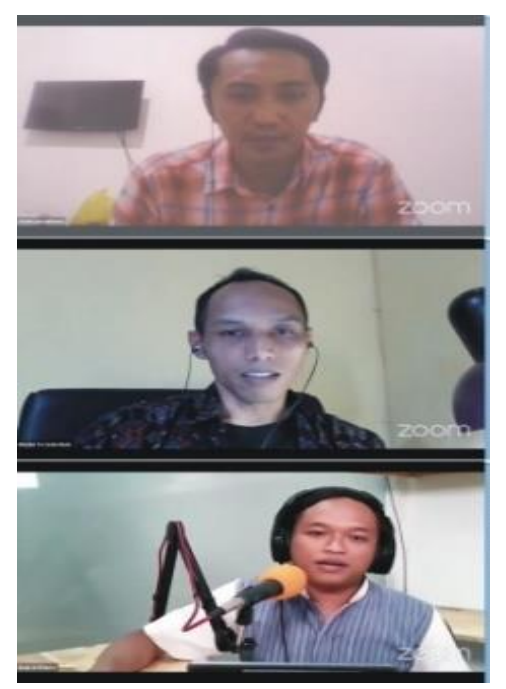

Gambar 1. Pemaparan materi dari narasumber

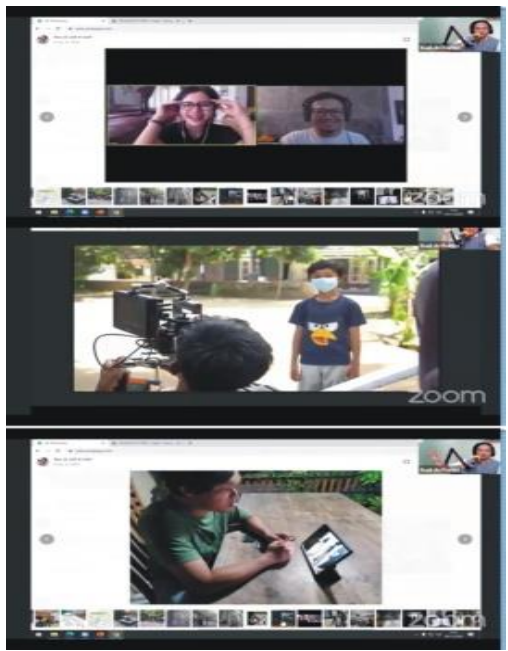

Gambar 2. Demontrasi produksi film di era new normal

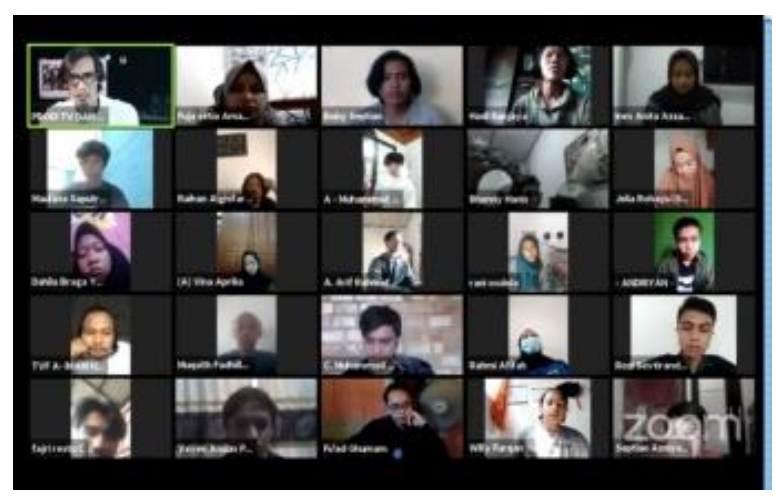

Gambar 3. Peserta kegiatan sosialisasi 
Hasil yang diperoleh dari sosialisasi ini menunjukkan bahwa peserta menyadari pentingnya untuk bangkit dan kembali melakukan produksi film. Peserta memahami tentang peran penting untuk menjaga keselamatan dan kesehatan saat melaksanakan produksi. Muncul inisiatif untuk berperan aktif secara positif dalam produksi film untuk kepentingan industri, kepentingan studi dan pengembangan sumber daya bidang industri kreatif. Sosialisasi ini menumbuhkan semangat baru dan menjawab kegamangan untuk memulai produksi karya film. Peserta memiliki petunjuk teknis yang dapat dijadikan pedoman dalam mengeksekusi gagasangagasan kreatif melalui cara-cara baru yang disesuaikan dengan kondisi new normal.

\section{SIMPULAN}

1. Bahwa produksi film di era new normal dapat dilakukan dengan menyesuaikan beberapa hal penting dalam produksi film yang meliputi penyesuaian ide dan penuturan cerita, tata cara penyelenggraan dan manajemen produksi, serta melakukan kompromi dengan berbagai peraturan dan anjuran tentang kesehatan. Tujuan utamanya adalah produksi film tetap berlangsung, dan kesehatan tetap terjaga.

2. Tujuan utama dari penyesuaian dalam produksi film adalah mencegah meluasnya penyebaran virus Covid-19. Cara melakukan penyesuaian adalah dengan mematuhi protokol kesehatan, memastikan bahwa semua yang terlibat dalam produksi film dalam kondisi sehat.

3. Pemilihan media distribusi, cara mengeksekusi ide-ide dengan berbagai pnyesuaian dalam era new normal harus disikapi sebagai optimisme bahwa dalam karya film akan ditemukan cara-cara baru dalam bertutur. Platform presentasi film berbasis internet akan menjadi media selanjutnya dalam presentasi karya seni film non-bioskop.

\section{UCAPAN TERIMA KASIH}

Terima kasih kepada nara sumber dan panitia penyelenggara, Asosiasi Program Studi Film dan Televisi (PROSFISI), Badan Perfilman Indonesia (BPI), asosisiasi profesi perfilman dan mahasiswa jurusan film seluruh Indonesia.

\section{DAFTAR PUSTAKA}

Armantono, R., \& Pramita, S. (2013). Teknik Penulisan Struktur Cerita Film. FFTV IKJ.

BPI. (2020). Protokol Produksi Audio Visual Pada Fase Pemulihan COVID-19. Badan Perfilman Indonesia.

Mas'udi, W., \& Winanti, P. S. (Eds.). (2020). New Normal, Perubahan Sosial Ekonomi dan Politik Akibat COVID-19. Gadjah Mada University Press.

Noor, M. (2020). Transformasi dan Tantangan dalam Urusan Publik di Era New Normal. FISIP UNTAG Semarang, 41-60.

Pats, D. (2010). Film Production Management. Michael Wiese. 